\title{
FAMILY RESOURCES MANAGEMENT AND LIFE SATISFACTION OF ELDERLY
}

\author{
Asri Sulistyowati $^{1 *}$, Diah Krisnatuti ${ }^{2}$ \\ ${ }^{1}$ Program Study of Family and Consumer Sciences, Faculty of Human Ecology, Bogor \\ Agricultural University, Bogor, 16680 \\ ${ }^{2}$ Lecturer in the Department of Family and Consumer Sciences, Faculty of Human \\ Ecology, Bogor Agricultural University, Bogor 16680 \\ *Corresponding author: asrisulistyowati8@gmail.com
}

\begin{abstract}
Elderly especially widower and widow must have done family resources management (FRM) in order to achieve satisfaction in life. This study was conducted to analyze the influence of family resource management on life satisfaction of elderly widower and widow. This study was using cross-sectional study with purposive for site selection in Timbulharjo Village, Sewon Subdistrict, Bantul, Yogyakarta Province. Total of 60 samples were gathered with a combination of simple random sampling and snow-ball techniques. The results of this study indicated atsocioeconomic status of the widower was higher in terms of average age and duration of education rather than widows, moreover the income of elderly widower greater than the widows. Non-food expenditure, stress management, and time management had a positive effect on the satisfaction of elderly life hence the more allocation on non-food expenditure, the better of stress management and time management could improve life satisfaction of the elderly. In addition, marital status associated and had a significant negative effect towards life satisfaction which mean that life satisfaction of elderly widower higher than the widow.
\end{abstract}

Keywords: elderly widower-widows, family resources management, life satisfaction.

\begin{abstract}
Abstrak
Lansia terutama yang berstatus duda dan janda tetap harus melakukan manajemen sumber daya keluarga (MSDK) untuk mencapai kepuasan hidupnya. Penelitian ini bertujuan untuk menganalisis pengaruh manajemen sumber daya keluarga terhadap kepuasan hidup lansia duda dan janda. Desain penelitian menggunakan cross sectional study dengan pemilihan lokasi secara purposive di Desa Timbulharjo Kecamatan Sewon, Kabupaten Bantul, Provinsi D.I Yogyakarta. Sebanyak 60 orang lansia yang diambil menggunakan kombinasi teknik simple random sampling dan snowball. Hasil penelitian ini menunjukkan karakteristik sosial ekonomi lansia yaitu rata-rata usia dan lama pendidikan yang ditempuh lansia duda lebih lama dibandingkan lansia janda, begitu juga pendapatan lansia duda juga lebih besar dibandingkan lansia janda. Pengeluaran nonpangan, manajemen stres dan manajemen waktu berpengaruh positif terhadap kepuasan hidup lansia, sehingga makin banyak alokasi pengeluaran nonpangan, semakin baik manajemen stres dan manajemen waktu mampu meningkatkan kepuasan hidup lansia. Selain itu, status perkawinan berhubungan dan
\end{abstract}


berpengaruh negatif signifikan dengan kepuasan hidup lansia artinya kepuasan hidup lansia duda lebih tinggi dibandingkan lansia janda.

Kata kunci: kepuasan hidup, lansia duda-janda, manajemen sumber daya keluarga.

\section{Introduction}

According to Constitution No. 13 of 1998, elderly is someone who has reached 60 years of age or over. Elderly in Indonesia increasing annually and the population has been predicted to reach 11,83 percent in 2025 and 15,77 percent in 2035 . This shows Indonesia has entered the era of aging population. According to BPS (2015) elderly people whose age 60 years old and over exceeds 7 percent of total population Indonesians, resulting in an increased of life expectancy. The increase in life expectancy is expected to be consistent with the life satisfaction perceived by the elderly. Life satisfaction is the psychological well-being felt by a person as a whole (Santrock, 2002). According to Erikson (1996) in Papalia et al., (2008) elderly is at the ego of integrity versus despair stage, thus the peak performance in late adulthood will be reflected by satisfaction with achievement in their life. Level life satisfactionLife satisfaction's level of Spaniards and Italians differed in three-time frames those are past, present, and future. Mauceri et al., (2013) found that Spaniards were more satisfied than Italians in all aspects of their future life over respect for social, physical and environmental relationships.

The elderly have developmental tasks that must have had done achieved for life satisfaction, one of which is to be able to adjust in various changes both positively and negatively whereas required adaptation process more than ever before. The elderly skin becomes pale and less elastic, the body became short with a weakening of vertebral bones, loss or shrinking nerve cells, impairment of vision and hearing function (Papalia et al., 2008). As aging is elevating, the percentage of elderly people that experience health problems increasing either. BPS (2015) stated as many as 48,30 percent of young elderly have health issues, as well as middle elderly reached 55,11 percent, and the highest percentage is equal to 57,96 percent. In addition, the elderly also experienced the process of losing spouse due to either divorce or death. BPS (2015) mentioned the pattern of marital status between elderly male population and womenfemale is different. caused by Divorce elderly women caused by death $(56,04 \%)$, while the men caused of remarried status $(82,84 \%)$. This is in line with Papalia et al., (2008) elderly women tend to choose widowhood compared to men.

All these changes require the elderly to adapt with family resource management that consist of stress, time, and financial management to achieve the expected life satisfaction. Management is a process which composed by planning, organizing, actuating, and controlling determined by humans and other resources to attain goals (Herujito, 2001). Resources is one of the factor of elderly's life satisfaction (Nisa, 2014). By type, resources divided into human and material resources. Human resources include cognitive, affective, and psychomotor aspects and also the skills, knowledge, and abilities of family members; while the encapsulated material resources are goods/services, time, and energy (Deacon \& Firebaugh, 1988). Family resource management is the process of using and allocating resources to achieve goals through planning and decide the necessary steps to meet the goals (Deacon \& Firebaugh 1988). Dollahite (1991) in Moktar et al., (2015) have pointed out stress management is an 
activity of managing stressors and decision making by using resources include seeking information, clarifying values, planning, considering alternatives and goals in the family. Time management according to Wingard (2007) in Malatras (2016) is the allocation of time, organizing activities and prioritize arrangements in family activities in order to organize family life. Financial management is a series of tasks to maximize interest earnings, minimize costs, and ensure the availability of funds for daily needs, household expenses, emergency conditions, savings and investment opportunities (Garman \& Forgue, 2000).

Elderly experienced changes cause they tend to be more stressful than previous life. Previous research conducted by Lee et al., (2012) states that the elderly experienced two most powerful pressures associated with perceived depression, namely health stress and financial stress. According to Lei et al., (2014) depression can caused death. In addition, the elderly social life affects their health, therefore it is requiring to build strong family support (Brinda, Gerdtham, \& Enemark, 2016; Wall, 2002). Lonesome elderly women tend to suffer from cardiovascular system disease and diabetes but not for elderly men (Christiansen, Larsen \& Lasgaard, 2016). According to Balachandran et al., (2007) elderly women experience more alienation rather than men regard of changes in family structure and social values due to the decline of marital status to widower and widow. Furthermore, the elderly widower and widow have any difficulty in doing management in life. Sunarti et al., (2013) study showed only one in seven families accustomed managing time efficiently indicating their deficient abilityin . In contrast, Matthews et al., (2013) stated elderly widows are quite satisfied with their financial situation.

Based on the description, researcher found interest to know family resources management and life satisfaction of the elderly widower and widow, as the process which have not been studied. In general, this study aims to identify the effect of family resource management on the life satisfaction of the elderly widower and widow. The study also assesed the difference of socio-economic characteristics, family resource management consisting of stress management, time, and finance along with expenditure allocation, and life satisfaction between widower and widows. In addition, by knowing the elderly life satisfaction as the output is expected to help the elderly view and their lives in a positive way, so there will be no regret during their life.

\section{Method}

\section{Research Design and Location}

This study used cross-sectional study design by analyzing the life satisfaction of widower and widows performed at one particular time and using questionnaires to collect the data. The selection of research sites was conducted purposively in Timbulharjo Village, Sewon District, Bantul Regency, Yogyakarta Province. The reason for choosing the location of the study was based on data from the D.I. Yogyakarta (2015) that Sewon District has the largest number of elderly in Bantul Regency in which the region has the second largest number of elderly in D.I Province of Yogyakarta and also the characteristic of the area still purely rural. The execution time was conducted three months starting from February 2017 until April 2017 covering the preparation phase, data collection, data processing, data analysis and report writing.

\section{Samples and Sampling Techniques}


Samples of this study were elderly people aged 60 years old or over who had been death divorce and live divorce more than two years. Researchers set the number of samples as many as 60 elderly consist of 30 elderly widower and 30 elderly widows with the assumption that the number has met the needs of statistical data processing. The sampling technique used a combination of simple random sampling and snow-ball with consideration of difficulties finding elderly widower, less validity of self-data samples provided by the village government and the researchers do not have the backup samples used to replace the invalid sample data.

\section{Variabel, Data Collection Method and Variable Measurement}

Primary data collection was using questionnaires developed and modified by researchers in pursuance of the needs that include socioeconomic characteristics of the elderly: family resource management consists of stress management using a COPE Inventory Questionnaire from Carver et al., (1989) with Cronbach's alpha value 0,738; time management examined using Rusydi (2011) questionnaire with Cronbach's alpha value 0,795; and financial management assesed through Firdaus \& Sunarti (2009) questionnaire with Cronbach's alpha value 0,857 and deepening the source of income, the allocation of food and non-food expenditure; and elderly life satisfaction as the output of this study was assesed using the questionnaire Neurgaten et al., (1961) with Cronbach's alpha value 0,829 and secondary data obtained from related institutions and literature. The total questionnaires has 70 items statements consist of 50 items related to the management of family resources and 20 items related to the satisfaction of life of the elderly. All questionnaires in the study used five scoring scales: $1=$ Strongly Disagree; $2=$ Disagree; 3 = Neutral; 4 = Agree $5=$ Strongly agree.

\section{Processing and Data Analysis}

The data were processed using Microsoft Excel and Statistical Package for Social Science (SPSS) 16 for Windows. wasProcessing data by editing, coding, scoring, entering, cleaning, and analyzing. Data analyses was conducted using descriptive statistics to explain socioeconomic status of elderly (age, sex, marital status, employment status, education duration, income, number of children and number of family members), stress management, time management, financial management and life satisfaction which divided into Bloom's cut-off category according to Ahmed (2007) : low (0-59), moderate (60-80) and high (81-100). In addition, a different sample (independent sample t-test) was conducted to analyze the differences between variables based on marital status (widower or widow); and multiple linear regression test to analyze the influence of socio-economic characteristics of elderly, stress management, time management, and financial management on life satisfaction of the elderly widower and widow.

\section{Findings}

\section{Characteristics Elderly}


The results shown that there were no significant differences $(\mathrm{p}=0,207)$ between of the average age between elderly widower (76,80 years) and widow (73,50 years). Nearly half of the elderly widower $(43,30 \%)$ classified as old elderly and half elderly widow $(43,30 \%)$ classified as young elder. t-testindicate sMore than half of the elderly widows $(53,30 \%)$ had 0 years (out of school) education duration and about widower (40\%) five onlyonly one to five years (no completion of primary school) and the average duration education of ofthe elderly widower is 5 years and widow only 3 years. a As many as 53,30 percent of elderly widower and widows were not working but the rest $(46,70 \%)$ were still workers. In total, 42,90 percent of the elderly widower work as farmers, while each 35,75 percent of the elderly widows work as laborers and traders. Revenues earned per month of elderly widows $(33,30 \%)$ are in the category of Rp 500.001- Rp 1.000.000 and about one-third of the elderly widower (30\%) are in the category less than or equal to Rp 500.000. The number of children owned by the elderly widower $(70 \%)$ are 1 to 4 children, while more than half of the elderly widows $(60 \%)$ have 5 to 7 children. Meanwhile almost half $(43,30 \%)$ of the widow elderly and widows live as small families (less than or equal to 4 family member).

\section{Income}

Minimum income of the elderly widower and widows are $\mathrm{Rp} 0$ as because they are not working and as many 53.30 percent elderly widow in this stage. The source of their income could be from work, given by children, grandchildren, and others. NearlyMoreover, hMoreover 50 percentalf of and four of widows do not earn extra money from their children. Mostly elderly widower and window do not get extra money from their daughters-in-law, grandchildren, and others. By reason of most the elderly living with the family and all the basic needs is filled. The largest average income of elderly widower comes from the provision of law ( $R p 1.200 .000)$ and the widow elderly from work ( $R p$ 749.000). Overall the average total income of elderly widower ( $R p$

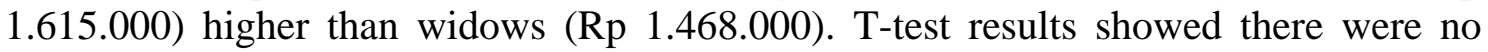
significant differences between elderly widower and widow $(p>0,05)$.

\section{Expenditure Allocation}

The allocation of expenditure covers both food and non-food expendicture. Food expenditure includes consumption measures through foodstuffs, while non-food expenditures include costs for health, electricity bills, water bills, transportation costs, clothing, contribution fees, hygiene and social benefits. The minimum number of food and non-food expenditure the elderly widower and widow equals $\mathrm{Rp} 0$ and there is no real difference between food expenditure in elderly widower $(\operatorname{Rp} 183.500)$ and widow (Rp 395.700). The largest total expenditure of elderly widower used for non-food ( $\mathrm{Rp}$ 190.300) and forwidow spent for food (Rp 395.700). There were significant differences between $(p=0,014)$ expenditure on electricity and water bills of the widower $(R p 3.800)$ and widow (Rp 19.800). The proportion of non-food expenditure $(50,91 \%)$ of elderly widower greater than food $(49,09 \%)$ while the proportion of food $(65,92 \%)$ of widow greater than non-food $(34,08 \%)$. Almost all elderly widower $(86,70 \%)$ and widow $(80 \%)$ had incomes more than or equal to expenditures, only 13,30 percent of the widower and 20 percent of widow who have less than expenses. Also Tthe t-test results showed no significant difference between the ratio of income and expenditure between the elderly widower and widow $(\mathrm{p}=0,497)$. 
Table 1 Percentage statistics of food and non-food expenditure (Rp thousand/month) based on marital status

\begin{tabular}{|c|c|c|c|c|c|c|c|}
\hline \multirow{2}{*}{ Category } & \multicolumn{3}{|c|}{ Widower } & \multicolumn{3}{|c|}{ Widow } & \multirow{2}{*}{ p-value } \\
\hline & Min & Max & Average & Min & Max & Average & \\
\hline Total Food Expenditure & 0 & 900 & 183,5 & 0 & 2.130 & 395,7 & 0,937 \\
\hline \multicolumn{8}{|l|}{ Non-food expenditure: } \\
\hline Health & 0 & 60 & 11 & 0 & 200 & 22,8 & 0,240 \\
\hline Electricity and water bills & 0 & 55 & 3,8 & 0 & 105 & 19,8 & $0,014 *$ \\
\hline Transportation & 0 & 420 & 29,3 & 0 & 800 & 28,7 & 0,983 \\
\hline Clothes & 0 & 95 & 4,3 & 0 & 100 & 11,7 & 0,232 \\
\hline $\begin{array}{l}\text { Contribution of harmony } \\
\text { and cleanliness }\end{array}$ & 0 & 15 & 1,1 & 0 & 30 & 2,3 & 0,412 \\
\hline Social Needs & 0 & 1.360 & 141,5 & 0 & 647 & 99,6 & 0,501 \\
\hline $\begin{array}{l}\text { Total non-food } \\
\text { expenditure }\end{array}$ & 0 & 1.440 & 190,3 & 0 & 1.700 & 204,6 & 0,868 \\
\hline Total expenses & 0 & 1.640 & 373,8 & 0 & 2.393 & 600,3 & 0,081 \\
\hline
\end{tabular}

\section{Stress Management}

The average answer regard of stress management, elderly widower had higher than the widow on the aspect of "not angry and able to withstand emotions and feelings to come out", "prefer watching television or listening to the radio" to reduce the mind and thinking hard about how to solve the problem. Meanwhile, the average answer on the aspect of "seeking advice from someone about what steps should be taken", "trying to find comfort in religion" such as following religious activities and not making problems worse by acting too quickly dominated higher by elderly widows than widower. The ttest results shows stress management between of the elderly widower and widow were different $(\mathrm{p}<0,05)$. Meanwhile, the elderly widower and widow alike do not make a strategy in solving the problem and let others intervene in solving the problem.

\section{Time Management}

The average answer to almost all aspects of time management of elderly widow is higher than widower especially on the aspect of planning weekly activities and arranging sequences of activities in order to meet personal and family needs. These results are supported by t-test showing there was were significant differences $(p<0.05)$ between elderly widower and widow.

\section{Financial Management}

Elderly widows higher than widower in terms of financial management, especially on the aspect of planning expenses every month $(p=0,028)$. There wasThe widow elderly did not calculate the estimated daily living expenses, did not compare receipts and expenses, did not separate money appropriately, did not plan the monthly the expenses and did not refer to pre-purchase plans. But, both the elderly widower and widow had not donet allocation money, evaluate expenditures regularly and thoroughly and when purchasing do not refer to the plan.

Table 2 The statiscal variability of the elderly family resource management based on marital status

Family Resource Management $\quad$ Widower $\quad$ Widow p-value




\begin{tabular}{|c|c|c|c|c|c|}
\hline & Min-max & Average & Min-max & Average & \\
\hline \multicolumn{6}{|l|}{ Stress management } \\
\hline $\begin{array}{l}\text { Think hard about the steps to resolve } \\
\text { the problem }\end{array}$ & $2-5$ & 3,87 & $2-5$ & 3,40 & $0,044^{*}$ \\
\hline $\begin{array}{l}\text { It does not make matters worse by } \\
\text { acting too quickly }\end{array}$ & $2-5$ & 3,43 & $2-5$ & 3,83 & $0,046^{*}$ \\
\hline $\begin{array}{l}\text { Trying to get someone's advice on } \\
\text { what to do }\end{array}$ & $2-5$ & 3,53 & $2-5$ & 3,90 & $0,052 *$ \\
\hline $\begin{array}{l}\text { Trying to find comfort in my religion } \\
\text { (following religious activities) }\end{array}$ & $2-5$ & 3,67 & $2-5$ & 4,23 & $0,024 *$ \\
\hline $\begin{array}{l}\text { Doesn't angry with holding emotions } \\
\text { and feelings to get out }\end{array}$ & $2-5$ & 4,27 & $2-5$ & 3,70 & $0,019 *$ \\
\hline $\begin{array}{l}\text { Watching TV or listening the radio to } \\
\text { reduce the thought. }\end{array}$ & $2-5$ & 4,30 & $2-5$ & 3,63 & $0,007 *$ \\
\hline Time management & & & & & \\
\hline Plan weekly activities & $2-5$ & 3,63 & $2-5$ & 4,13 & $0,025^{*}$ \\
\hline $\begin{array}{l}\text { Arrange the order of activities in order } \\
\text { to meet personal and family needs }\end{array}$ & $2-5$ & 3,63 & $2-5$ & 4,10 & $0,029 *$ \\
\hline $\begin{array}{l}\text { Financial management } \\
\text { Plan the use of monev every month }\end{array}$ & $2-5$ & 2.97 & $2-5$ & 3.63 & $0.028 *$ \\
\hline
\end{tabular}

Stress management of elderly widower and widow had highest point, while the lowest handed over financial management but overall categories classified as moderate. Stress management conducted by almost all elderly widows (90\%) and more than threequarters of the elderly widower $(76,70 \%)$ reached the medium category. Means of stress management between the elderly widower $(71,83)$ and widow $(71,57)$ showed no differences $(\mathrm{p}=0,898)$. Time management reached medium category performed by nearly three quarters of the elderly widow $(73,60 \%)$ and more than half of the elderly widower $(60 \%)$. The mean of age management index of widow elderly $(70,61)$ was better than the widower $(67,78)$ and supported by different test result which showed there were no differences between the elderly widower and widow $(\mathrm{p}=0,318)$. Almost two-thirds of the elderly widower $(63,30 \%)$ and nearly half of the elderly widow $(46,70 \%)$ reached low category of financial management. The average of elderly widow $(60,65)$ higher than widower $(51,85)$, and there were no differences between the elderly widower and widow $(p=0,066)$. Overall, the achievement of family resources management of the elderly widower and the widow classified as moderate (80\%) with the means of the elderly widow $(69,32)$ is better than the widower $(67,02)$. There were no significant differences between the elderly widower and elderly widow $(p=0,093)$.

Table 3 Distribution of elderly based family resource management and marital status

\begin{tabular}{|c|c|c|c|c|}
\hline \multirow{2}{*}{ Family Resource Management } & \multicolumn{2}{|c|}{ Widower } & \multicolumn{2}{|c|}{ Widow } \\
\hline & $\mathrm{n}$ & $\%$ & $\mathrm{n}$ & $\%$ \\
\hline \multicolumn{5}{|l|}{ Stress management } \\
\hline Low $<60$ & 2 & 6,70 & 1 & 3,30 \\
\hline Medium 60-80 & 23 & 76,70 & 27 & 90,00 \\
\hline High $>80$ & 5 & 16,70 & 2 & 6,70 \\
\hline Total & 30 & 100,00 & 30 & 100,00 \\
\hline Min-Max ( Index ) & & & & \\
\hline Average \pm SD ( Index ) & 71,83 & & 71,57 & \\
\hline p-value & \multicolumn{4}{|c|}{0,898} \\
\hline \multicolumn{5}{|l|}{ Time management } \\
\hline Low $<60$ & 8 & 26,70 & 3 & 10,00 \\
\hline Medium 60-80 & 18 & 60,00 & 23 & 76,70 \\
\hline
\end{tabular}




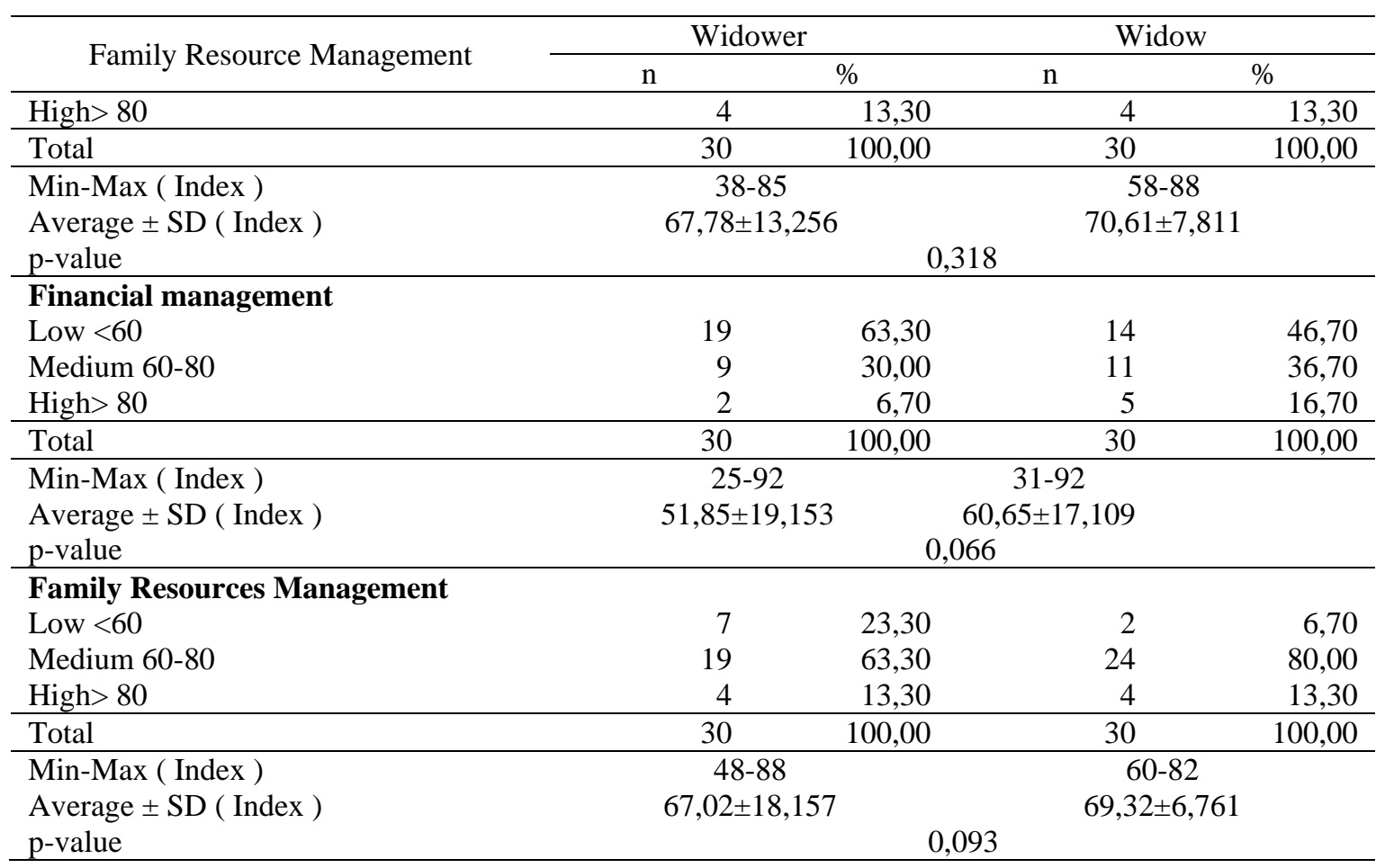

\section{Life Satisfaction}

Elderly widower dominated almost all aspect of life satisfaction especially the statement ofabout regret having wrong decision in the past. While on the aspect of "activities that do not boring" or "monotonous answer" the elderly widow is higher than widower. These results are proven by different test results that show significant differences between elderly widower and widow $(\mathrm{p}<0,05)$.

More than three quarters of elderly widow $(76.70 \%)$ and widower $(73,30 \%)$ are in the medium category pertaining to life satisfaction. There were 20 percent of elderly widow whose in the low category and also widower (10\%) and the rest reached the high cluster. Average of life expectancy index of the elderly widower $(71,75)$ higher than widow $(65,50)$ reinforced with t-test result which shows there is real difference between the elderly widower and widow $(\mathrm{p}=0,012)$.

Table 4 Distribution of elderly based on life satisfaction and marital status

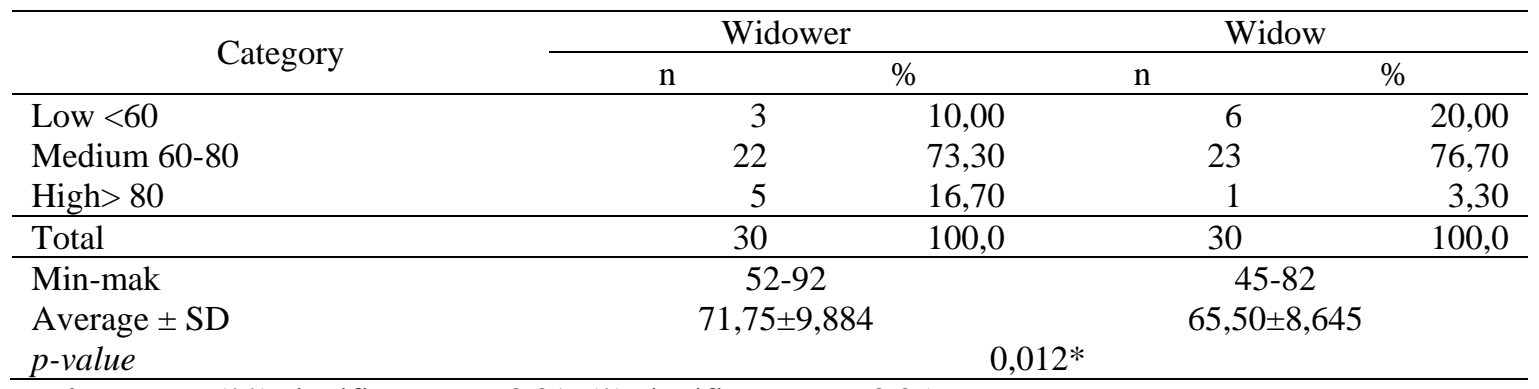

Information. $(* *)$ significant at $\mathrm{p}<0,01 ;(*)$ significant at $\mathrm{p}<0,05$.

Effects of Socio-Economic Characteristics, Stress Management, Time Management, and Financial Management on Elderly Life Satisfaction 
Overall regression model with an adjusted $\mathrm{R}^{2}$ value of 0,487 or equivalent to 48,70 percent of variables in this study could affect the satisfaction of elderly life, while the rest of 51,30 percent influenced by other factorsthat has been . Marital status variables had a significant negative effect $(p<0,05)$ to life satisfaction of elderly, meaning widow marriage status will decrease life satisfaction of elderly. Conversely, stress management variables had a positive significant influence $(p<0,05)$ towards life satisfaction of elderly, meaning that one point increased of stress management gainedelevating life satisfaction of elderly by 0,378 points. Time management had a possitive significant effect $(\mathrm{p}<0,01)$ on elderly's life's satisfaction, in a sense that every increase of one time management unit will increase the life satisfaction of the elderly by 0,363 points. In addition, non-food expenditure on financial management also had a significant positive effect $(p<0,05)$ on the satisfaction of elderly life, meaning that each one unit rupiah of non-food expenditure will increase the life satisfaction of the elderly by 1,630 points.

Table 5 Regression coefficients between socioeconomic characteristics, stress management, time management, financial management and life satisfaction of the elderly

\begin{tabular}{|c|c|c|c|}
\hline \multirow{2}{*}{ Variables } & \multicolumn{3}{|c|}{ Life satisfaction of elderly } \\
\hline & B & B & Sig. \\
\hline Age (years) & 0,154 & 0,159 & 0,240 \\
\hline Marital status $(0=$ widower; $1=$ widow $)$ & $-5,020$ & $-0,260$ & $0,020^{*}$ \\
\hline Job status $(0=$ not working, $1=$ work $)$ & $-1,418$ & $-0,073$ & 0,691 \\
\hline Duration of education (years) & $-0,153$ & $-0,580$ & 0,626 \\
\hline Revenue (Rp thousand / month) & 1,818 & 0,318 & 0,554 \\
\hline Food expenditure (rupiah) & $-0,218$ & $-1,772$ & 0,082 \\
\hline Non-food expenditure (rupiah) & 1,630 & 0,360 & $0,014 *$ \\
\hline Number of children (people) & $-0,174$ & $-0,036$ & 0,761 \\
\hline Number of family members in one house (person) & $-0,056$ & $-0,021$ & 0,830 \\
\hline Stress management (index) & 0,378 & 0,298 & $0,036^{*}$ \\
\hline Time management (index) & 0,363 & 0,406 & $0,008 * *$ \\
\hline Financial management (index) & $-0,790$ & $-0,150$ & 0,280 \\
\hline $\mathrm{F}$ & & 5,000 & \\
\hline $\mathrm{R}^{2}$ & & 0,609 & \\
\hline Adjusted $R^{2}$ & & 0,487 & \\
\hline Sig & & $0,000 * *$ & \\
\hline
\end{tabular}

Information. $(* *)$ significant at $\mathrm{p}<0,01 ;(*)$ significant at $\mathrm{p}<0,05$.

\section{Discussion}

The results showed the average age of elderly widower older than the widow. Conversly BPS (2015) finding which stated women's life expectancy is higher than male's. In case of education duration elderly widower better than the widow and this is in line with Kusumo \& Simanjuntak (2009) study that the level of education of the husband is better than the wife's education level with more than half of the husbands completed school up to elementary level, while the wife never sat in school.

The more high education that elderly get will followed by higher income and the more educated and wealthy the elder will feel and achieved life satisfaction (Nisa, 2014). In this study, the largest average income of elderly widower came from the provision of a son-in-law, whereas the average income source of the elderly widow was 
from work. This is supported by the findings from Rahmaniah (2015) which showed elderly widower had a higher financial ability than widows. Elderly widow spend more money on food expenditure. These findings are consistent with the findings of Firdaus, Apriliani, \& Wijaya, (2013); Girsang, (2012); Muflikhati, (2010); Rambe, Hartoyo, \& Karsin, (2008) that the average family expenditure, especially in poor families is still dominated for food expenditure. In contrast, elderly widowers spend the money for nonfood expenditures. The condition of elderly widower according to Engel Theory which stated those who have had high income will spend their money more on non-food consumption. Overall, the expenditure on food and non-food of the elderly widow is bigger than the widower. This is due to the elderly widow in this study were still helping and managing finances in order to be able to meet the needs of family food such as shopping and cooking. In contrast, the elderly widower in this study lives with the family and all the food needs were fulfilled by the family, thus the money that goes to non-food sector are social activities for instance social gathering, gathering with the community, and holiday with friends as Rozanova (2010) said that the limitations of his resources affect the ability of the elderly to enjoy old age and meet his expectations for success. The expenditure for food and non-food of the elderly widow has exceeded the poverty line established by BPS Provinsi DI Yogyakarta (2016). On the other hand, the expenditure of elderly widower food is Rp 180.500 still below the predetermined poverty line, but non-income of the elderly widower of Rp 190.300 has already exceeded the poverty line. BPS Provinsi DI Yogyakarta (2016) stipulates the minimum amount that must be issued for food is $\mathrm{Rp} 250.244$ and $\mathrm{Rp} 86.986$ for non-food expenditure in rural areas.

Overall achievement of resource management of elderly family is moderate, with an achievement of elderly widow better than the widower. Related to stress management, the elderly widower better than widow, and stress management both are in the category of being. This is supported by Wilcox et al., (2003) findings that elderly widowhood weaker than the elderly married women in social function, mental health as a whole and depressed. In this study the elderly widower was able to withhold emotions, prefer watching television or listening to the radio to reduce their mind, and thinking hard about the steps to solve the problem. Meanwhile, the elderly widows chose seek an advice, comfort themselves in religion like following religious activities and not making matters worse by acting too quickly.

Time management of elderly widow better than widower but both classified in medium category. Elderly widow still plan weekly activities and arrange sequences of activities in order to meet personal and family needs. In contrast, elderly widower do planning time for rest and activities with family. The condition of the elderly widower in this study is in line with the findings of Hanh et al., (2011) which stated that the elderly widower spends and appreciate more time to interact with the family. In addition, the findings in this study are consistent with Papalia et al., (2008) the elderly widower tend to spend time with social contact with his friends. The study found that most elderly widows were accustomed from youth until become an elderly widow in managing their time to meet his family. This results in line with Hanh et al., (2011) that little evidence to support the stereotype of the weakening of the conditions causes the elderly widow to depend on others for a long time, and as a whole, there is no difference in the use of time between elderly widows and elderly married females. Related management of elderly widower and elderly widow are in the low category but elderly 
widow better than elderly widower especially in the monthly money planning. These results supported by Panda (2013) which found that the widow elderly have financial problems and are in very poor and poor category.

The average life satisfaction achieved by elderly widower. In addition, elderly widower tend to have better health performance, feel happy and satisfied with the achievements during his life. Nevertheless, this finding contradict with Balachandran (2007) life satisfaction of widower and widow were just in the same level. The mismatch of the results of this study with other's literature caused by widow's life were fulfilled by the family.

Marital status variables, stress management, time management and non-food expenditure affected the satisfaction of elderly life. Marital status is a variable that had significant negative effect with life satisfaction of elderly, meaning that life satisfaction of elderly widower higher than widow, according to findings Nisa (2014) which stated elderly widower have greater life satisfaction than elderly widow. Also stress management and non-food expenditure possitively affected on satisfaction. Grounded by widower spent their money to social need instead. Elderly in this study live in rural areas that still uphold mutual cooperation activities. In addition, the elderly have high awareness to be actively contributed in any social activity. Elderly's life satisfaction could be improved by social activities as its function to manage stress.. Also Sajin et al., (2016) said greater social engagement will be able to reduce the loneliness of stress, negative feelings and the creation of mutual relationships that can improve the quality of life of the elderly. In addition, according to Widyaningsih \& Muflikhati (2015), the non-food expenditure allocation used for social activities can affect the subjective wellbeing of the fishermen's family wives. Time management possitively influenced life satisfaction of elderly as Lapa (2013) stated that spare time related to the life satisfaction. In this study, there were no significant effect on financial management and lfie satisfaction. Notwithstanding Hakim et al., (2014) found that financial management is related and has an effect on life satisfaction. Limitations in this study are the nondetermination of age limit and data retrieval techniques using a combination of simple random sampling and snow-ball techniques thus the results less in describing the achievements of family resources management and life satisfaction of the elderly widower and widow.

\section{Conclusions and Recommendation}

\section{Conclusions}

This study the were no differences in socioeconomic characteristics of elderly between elderly widower and widow. The average achievement of stress management, time management, and life satisfaction of elderly are classified as moderate, meanwhile in financial management still categorized as low. In managing stress, widower better than widow in spite of that in managing financial widow achieved more than widower . Overall, management of elderly family resources is moderate although the average index of family resources management in elderly widows better than the widower. Furthermore, non-food expenditure variable, stress management, and time management had a positive effect on elderly's life satisfaction meaning that higher non-food expenditure, stress management and time management can increase life satisfaction of elderly widower and widows. Widow marriage status negatively affects life satisfaction of elderly, this shows the status of widows decrease life satisfaction of the elderly. 


\section{Recommendation}

This study found that plenty of elderly people who have illiteracy doesn't work and have low income. Therefore, this study recommended that local governments expected to pay more attention and improve the condition of elder people through local regulations and assistance. In addition, the government in rural area can strengthen the Elderly Community Development program and revitalize the existing elderly's posyandu in each sub-village, then it is closer to the elderly condition and as a support the widower of widower to improve family resource management capability. The closest families of elderly widower and widow are expected to provide support, help and establish good communication with them to achieve life satisfaction. Further, research on family resource management and life expectancy of the elderly is expected to have more detailed characteristics in elderly, using better sampling techniques than this research and using unexplored variables that will enrich the study of elderly family science in Indonesia.

\section{Reference}

Ahmed, M. (2007). Faktor-faktor yang memengaruhi penduduk lanjut usia memilih untuk bekerja. Journal: Indonesia Applied Economics, 3(2), 99-110.

Akinlabi, F., (2013). Coping mechanism/resources of young and old widows in South West Nigeria. Journal: Social Sciences, 4(2), ISSN 2039-2117 (online), ISSN 2039-9340 (print)

Badan Pusat Statistik. (2015). Statistik Penduduk Lanjut Usia Indonesia 2015. Diunduh dari http: // www.bps.go.id/ website/ pdf_publikasi/ Statistik-Penduduk-LanjutUsia-2015--.pdf

Balachandran, M., Rakhee, A.S., Raj, S.S., (2007). Life satisfaction and alienation of elderly males and females. Journal: The Indian Academy of Applied Psychology, 33(2), 157-160. Diunduh dari http:/ /medind.nic.in /jak/t07 /i2/ jakt 07i 2p157. pdf.

Brinda, E.M., Gerdtham, U.G., \& Enemark, U., (2016). Socio-economic inequalities in health and health service use among older adults in India: results from the WHO Study on Global AGEing and adult health survei. Journal: Public health, 141 (2016), 32-41.

Carver, C.S., Scheier, M.F., Weintraub, J.K., (1989). Assessing coping strategies- a theoretically based approach. Journal of Personality and Social Psychology, 56(2), 267-283. doi: 10.1037/0022-3514.56.2.267.

Deacon, F., Firebaugh, F.M., (1988). Family resource management principles and applications (Second Edition). Massachusetts: Allyn and Bacon Inc.

Firdaus, M., \& Sunarti, E., (2009). Hubungan antara tekanan ekonomi, dan mekanisme koping dengan kesejahteraan keluarga wanita pemetik teh. Jurnal: Ilmu Keluarga dan Konsumen, 2, 21-31. Diunduh dari http: // google.com// journal.ipb.ac.id//\%\%2F5160\%2F3538\&usg.pdf

Firdaus, M., Apriliani, T., Wijaya, R.A., (2013). Pengeluaran rumah tangga nelayan dan kaitannya dengan kemiskinan: Kasus di Desa Ketapang Barat, Kabupaten Sampang, Jawa Timur. Jurnal: Sosial Ekonomi, 8(1). 
Garman, E.T., \& Forgue R.E., (2000). Personal finance, sixth edition. Boston, US: Houghton Mifflin Publishing

Girsang, W. (2012). Analisis pendapatan rumah tangga dan kemiskinan di pedesaan Maluku (studi kasus di Desa Lohiatala Kabupaten Seram bagian Barat, Provinsi Maluku). Jurnal : Agrinimal, 2(2), 44-54.

Hakim, F.A., Sunarti, E., Herawati, T., (2014) . Manajemen keuangan dan kepuasan keuangan istri pada keluarga dengan suami istri bekerja. Jurnal: Ilmu Keluarga dan Konsumen, 7(3), 174-182, ISSN 1907-6037.

Hahn, E., Cichy, B.K.E., Almeida, M., Haley, W.E., (2011). Time Use and Well-being in Older Widows: Adaptation and Resilience. Jurnal: Women Aging, 23(2), 149159. doi: 10.1080/08952841.2011.561139.

Herujito Y.M., (2001). Dasar-Dasar Manajemen. Jakarta (ID): Grasindo

Kusumo, R.A.B.,\& Simanjuntak, M., (2009). Tingkat kepuasan keluarga berpendapatan rendah terhadap sumberdaya yang dimiliki. Jurnal: Ilmu Keluarga dan Konsumen, 2(2),122-136,ISSN: 1907-6037

Lapa, T.Y., (2013). Life satisfaction, leisure satisfaction and perceived freedom of park recreation participant. Journal; of Social and Behavioral Sciences, 93(2013), 1877-0428. doi : 10.1016/j.sbspro.2013.10.153.

Lee, C.T., Yeh, C.J., Lee, M.C., Lin, H.S., Chen, V.C., Hsieh, M.H., Yen, C.H., \& Lai, T.J., Leisure activity, mobility limitation and stress as modifiable risk factors for depressive symptoms in the elderly: Results of a national longitudinal study. Journal: Gerontology and Geriatrics, 54(2012), e221-e229. doi : 10.1016/j.archger.2011.06.014.

Lei, X., Sun, X., Strauss, J., Zhang, P., Zhao, Y., (2014). Depressive symptoms and SES among the mid-aged and elderly in China: evidence from the China Health and retirement longitudinal study national baseline. Journal: Social Science and Medicine, 120(2014),224-232.

Malatras, J.W., Israel, A.C., Sokolowski, K.L., \& Ryan, J., (2016). First things first: family activities and routines, time management and attention. Journal of Applied Developmental Psychology, 47(2016), 23-29. doi: 10.1016/j.appdev.2016.09.006.

Matthews, A.M., Tong, C.E., Rosenthal, C.J.,\& Macdonald, L., (2013). Ethno-cultural diversity in the experience of widowhood in later life: chinese widows in Canada. Journal: Aging Studies, 27(2013), 507-518.

Mauceri, M., Licciardello, O., Dimarco, O.L.G., (2013). Psychosocial dimensions of Quality of Life among elders: a research of the Italian and Spanish elderly. Journal Social and Behavioral Sciences World Conference on Educational Sciences (WCES), 5(2013), 1877-0428. doi:10.1016/j.sbspro.2014.01.451.

Moktar, N., Husniyah, A.R., Sabri, M.F., \& Talib MA. 2015. Using Dollahite's ABCDXYZ Resource Management Model of Crisis or Stress as a Framework for Understanding Financial Well-being . Journal of Humanities and Social Science, 5(4), 219-228. Diunduh dari http: // www.ijhssnet.com /journals /Vol_5_No_4_April_2015/23.pdf.

Muflikhati, I. (2010). Analisis pengembangan model peningkatan kualitas sumber daya manusia dan kesejahteraan keluarga di wilayah pesisir Provinsi Jawa Barat 
(Disertasi). Sekolah Pascasarjana, Institut Pertanian Bogor, Bogor.

Neugarten, B.L., Havighurst, R.J., Tobin, S,S., (1961). The measurement of life satisfaction. Journal of Gerontology, 16(2), 134-143. doi: 10.1093/geronj/16.2.134.

Nisa, K. (2014). Sumber daya pensiun dan kepuasan hidup lansia pria dan wanita pada masa pensiun. Skripsi. Institut Pertanian Bogor, Bogor.

Panda B. (2013). Socio-economic problems of elderly widows In Puri Town, Orissa. Research Paper Sociology, 3(6), 501-502. ISSN 2249-555X.

Papalia, D.E., Olds, S.W., Feldman, R.D., (2008). Human Development (Psikologi Perkembangan). A,K., Anwar, penerjemah. Jakarta, ID: Kencana. Terjemahan dari : Human Development. Ed Ke-9.

Rahmaniah ,B.I., (2015). Ageism, generativitas, dan tugas perkembangan lansia duda dan janda. Skripsi. Institut Pertanian Bogor, Bogor.

Rambe, A., Hartoyo, \& Karsin, E. S. (2008). Analisis alokasi pengeluaran dan tingkat kesejahteraan keluarga (Studi di Kecamatan Medan Kota, Sumatera Utara). Jurnal: Ilmu Keluarga dan Konsumen 1(1), 16-28.

Rozanova, J., (2010). Discourse of successful aging in The Globe \& Mail: Insights from critical gerontology. Journal: Aging Studies, 24(2010), 213-222.

Rusydi, L.N., (2011). Analisis perbandingan manajemen sumberdaya dan kesejahteraan keluarga pada keluarga miskin dan tidak miskin. Skripsi: Fakultas Ekologi Manusia. Institut Petanian Bogor, Bogor.

Santrock, J.W., (2012). Perkembangan Masa Hidup Jilid II. Widyasinta B, Sallama, N.I., editor. Jakarta (ID): Erlangga. Terjemahan dari : Life Span Development $13^{\text {th }}$ ed. Ed Ke-13.

Sajin, N., Dahlan, A., Ibrahim, S.A.S., (2016). Quality of life and leisure participation amongst malay older people in the institution. Journal: Social and Behavioral Sciences, 234(2016), 83-89. doi: 10.1016/j.sbspro.2016.10.222.

Sunarti, E., Kholifah, I., Vidiastuti, F., Kharisma, N., Rochimah, N., \& Herawati, T., (2013) . Family vulnerability, family resource management, and family strength of aging family members. Paper presented at $5^{\text {th }}$ Internasional Work and Family Conference, University of Sydney, Australia.

Wall, R., (2002). Elderly widows and widowers and their coresidents in late 19th- and early 20th-century England and Wales. Journal: History of the Family, 7(2002), $139-155$.

Widyaningsih, E., Muflikhati, I., (2015). Alokasi pengeluaran dan kesejahteraan keluarga pada keluarga nelayan bagan. Jurnal: Ilmu Keluarga dan Konsumen, 8(3), 182-192. ISSN 1907-6037.

Wilcox, S., Aragaki, A., Mouton, C.P., Evenson, K.R., Smoller, W.S., \& Loevinger, B.L., (2003). The effects of widowhood on physical and mental health, health behaviors, and health outcomes: the women's health initiative. Jurnal: Health Psychology, 22(5), 513-522. doi: 10.1037/0278-6133.22.5.513. 